\title{
DIGITAL HERMENEUTICS AND A NEW FACE OF THE QUR'AN COMMENTARY The Qur`an in Indonesian`s Facebook ${ }^{1}$
}

\section{Fadbli Lukman}

Orientalisches Seminar, Albert-Ludwigs Universität Freiburg, Germany email:fadblilukman@gmail.com

\section{Abstract}

The $21^{\text {st }}$ history of the Qur'an sees the scripture's availaibility in the social media technology. This paper discusses the hermeneutical configuration of the Qur an commentary in social media, not as religious phenomena in sociological or anthropological perspective, but rather as a study of the history of exegesis. The paper addresses two points: the character of the Qur'an commentary presented in Facebook within the context of the modern Qur'anic commentary. The paper suggests that digital hermeneutics emerges as a step of popularizing commentary in modest and presentation. Accordingly, people are now closer to Qur anic interpretation than before, and therefore the upsurge of semantic function of the Qur an is on the way. At the same time, digital hermeneutics marks the phenomena of equality and democratization of participation in bermeneutical activity and the challenge of authority.

1 First draft has been presented in The $16^{\text {th }}$ Annual International Conference on Islamic Studies (AICIS) in Lampung, November 1-4, 2016 with the title "Digital Hermeneutics: The Qur'an in Indonesian's Facebook". I would like to thank Prof. Dr. Johanna Pink (Freiburg University) for reading the first draft of this article and giving invaluable remarks. This research was conducted under the funding of the project "Ein Nationalstaat als religiöser Akteur: Das Indonesische Religionsministerium (Kementerian Agama) und die Deutungshoheit über den Koran” by DFG (Deutsche Forschungsgemeinschaft). 
[Sejarah Al-Quran abad ke-21 ditandai dengan perkawinan kitab suci ini dengan teknologi sosial media. Paper ini mendiskusikan bangunan bermeneutis tafsir Al-Quran di sosial media, bukan sebagai fenomena keberagamaan dalam nuansa sosiologis dan antropologis, melainkan sebagai studi sejarah tafsir. Ada dua hal yang dikaji: tentang karakter tafsir Al-Quran yang muncul di Facebook dalam konteks tafsir modern dan pengarub yang dimunculkannya. Diskusi ini menyimpulkan bahwa digital hermeneutics muncul sebagai kelanjutan dari tafsir populer dengan penampilannya yang sederhana dan lugas. Oleh sebab itu, orang-orang saat ini menjadi semakin dekat dengan penafsiran Al-Quran, dan meningkatnya fungsi semantik Al-Quran menjadi jelas terlihat. Pada saat yang sama, digital hermeneutics menandai kesetaraan dan demokratisasi dalam partisipasi terbadap aktivitas hermeneutis Al-Quran dan tantangan terhadap otoritas.]

Keywords: digital hermeneutics, Qur`an commentary, facebook

\section{A. Introduction}

History shows a sustained integration between the Qur`an and technologies. From an exclusive, and costly bundle, to a popular digital screen, the Qur'an has been written, compiled, codified, published, recorded either in audio or video, and finally nowadays uploaded and freely accessed through internet. It is fair enough to say that the Qur'an has always been taken a step forward with improvement along with technology. On the other hand, the Qur'an also consistently forms the way Muslims live. Every step of the development the Qur'an has taken influences on the way Muslims approach it. Brett Wilson suggests that the printing of the Qur'an is in transition from an exclusive book to public one, and at the same time produced new intellectuals in the pre-modern Turkish history. ${ }^{2}$ Audio and video tapings changed the reception of the Qur'an as Abu Zayd says, "there is no need to attend the sessions of an expert shaykh or qäri' in order to learn tajwid", and "qur'anic recitation may be experienced through listening to a tape or compact disk". ${ }^{3}$ An

2 M. Brett Wilson, Translating the Qur'an in an Age of Nationalism: Print Culture and Modern Islam in Turkey (Oxford, New York: Oxford University Press, 2014), pp. 2-3.

3 Nasr Hamid Abu Zayd, "Everyday Life, Qur'ān In”, Encyclopaedia of the Qur'an, ed. by Jane Dammen McAuliffe (Leiden: Brill, 2002), pp. 90-4. 
ethnographical research by Anna M. Gade reveals that through call-in radio broadcasts, Muslims can express their piety as well as enjoy recitation of the Qur'an in a beautiful melody. ${ }^{4}$ It is clear that both the Qur'an and Muslims have a reciprocal relation.

Interactions of Muslims with the Qur'an are mostly studied within anthropology, such as by Anna M. Gade, Anne K. Rasmussen, ${ }^{5}$ William Graham, ${ }^{6}$ Ahmad Rafiq, ${ }^{7}$ to mention but a few. The interactions of Muslims' life and social media has so far been a promising field for anthropology, published in a special issue about practicing piety through social media in Indonesia by Indonesia and the Malay World. ${ }^{8}$ While anthropology is one of the approaches in studying this phenomena, to analyze its hermeneutical configuration is an other relevant way. That is because the basic interaction of Muslims with the Qur'an in social media is mostly hermeneutical; they write the Qur'an translations, commentaries, or personal opinion and reflection on their Facebook accounts. It is however, studies on hermeneutical works of the Qur'an so far have not yet taken the phenomena of social media and the Qur'an into account. What interest most scholars in this field are to study theoretical and methodological problems in interpreting the Qur'an in contemporary context or to examine some commentators. Nadirsyah Hosen in his monograph Tafsir Al-Quran di Medsos might the only one discussing tafsir in social media. However, what he does is not a research on Qur'an commentary in social media, but rather to clarify the widespread products of Qur'an commentary in social media; he was doing tafsir instead of explaining what happens within the development

4 Anna M. Gade, Perfection Makes Practice: Learning, Emotion, and the Recited Qur'an in Indonesia (Honolulu: University of Hawai'i Press, 2004).

5 Anne Rasmussen, Women, the Recited Qur'an, and Islamic Music in Indonesia (Berkeley: University of California Press, 2010).

${ }^{6}$ William Albert Graham, Beyond the Written Word: Oral Aspects of Scripture in the History of Religion (Cambridge: Cambridge University Press, 2001).

7 Ahmad Rafiq, "The Reception of the Qur'an in Indonesia: A case study of the place of the Qur'an in a non Arabic speaking community", Ph.D. Dissertation (Philadelphia: Temple University, 2014).

8 Martin Slama, "Practising Islam through Social Media in Indonesia", Indonesia and the Malay World, vol. 46, no. 134 (2018), pp. 1-4. 
of tafsir. ${ }^{9}$ It is also worth mentioning, there are studies dealing with hermeneutical configuration of popular literatures such as of Howard Federspiel, ${ }^{10}$ Islah Gusmian, ${ }^{11}$ and M. Nurdin Zuhdi. ${ }^{12}$ While these studies deal with published commentaries, the social media uses a different medium of the Qur'an commentaries. The failure to shed light on social media with regard to the involvement of Qur`anic material might be the consequence of a strict definition of 'tafsir' which excludes hermeneutical reception of lay Muslims. ${ }^{13}$

A hermeneutical study on the integration between the Qur'an and social media, digital hermeneutics, is now imperative. The media is the most read commentary in Indonesia today. Indonesia is one of the countries with most Facebook users. In 2013, Ministry of Communication and Information released a statistics that internet users in Indonesia are 63 millions, and $95 \%$ of them use social media. ${ }^{14}$ At the same time, Indonesia has the lowest reading rate. An article in The Jakarta Post quotes a recent study conducted by John Miller, president of Central Connecticut State University in New Britain, placing Indonesia as the second-lowest rank of

${ }^{9}$ Nadirsyah Hosen, Tafsir al-Quran di Medsos (Yogyakarta: Bentang Pustaka, 2017).

${ }^{10}$ Howard M. Federspiel, Popular Indonesian Literature of the Qur'an (Ithaca (NY): Cornell modern Indonesia project, Southeast Asia program, Cornell University, 1994).

11 Islah Gusmian, Khazanah Tafsir Indonesia: Dari Hermeneutika bingga Ideologi (Yogyakarta: LKiS, 2013).

12 M. Nurdin Zuhdi, Pasaraya Tafsir Indonesia: Dari Kontestasi Metodologi hingga Kontekstualisasi (Yogyakarta: Kaukaba, 2014).

13 Andreas Görke suggests that numbers of lay exegesis have come up, particularly if oral tafsìr or tafsīr of only part of the Qur`an are taken into account. With the density of hermeneutical activity in social media, it should not be ignored. Andreas Gorke, "Redefining the Borders of Tafsīr: Oral Exegesis, Lay Exegesis and Regional Particularities", in Tafsir and Islamic Intellectual History: Exploring the Boundaries of a Genre, ed. by Andreas Görke and Johanna Pink (London: Oxford University Press, 2014), pp. 361-78.

14 Kementrian Kominfo, "Kominfo: Pengguna Internet di Indonesia 63 Juta Orang," Kementrian Komunikasi dan Informatika, November 7, 2013, https:/ / kominfo. go.id/index.php/content/detail/3415/Kominfo+:+Pengguna+Internet+di+Indones ia+63+Juta+Orang/0/berita_satker., accessed 22 June 2017. 
61 countries in the low illiteracy rates. ${ }^{15}$ The comparison between these two statistics implies that Indonesians use their literacy proficiency for social media activities. As far as the Qur'an commentary is concerned, it leads to an assumption that Indonesians do not read the published commentaries from exegetes like Quraish Shihab or Hamka, but they read the works via social media.

To bridge this methodological gap and to academically deal with this phenomena, this paper talks about the integration of the Qur an hermeneutics and social media technology. Speaking hermeneutics, the Qur'anic exegesis has broadest meanings, including any forms of hermeneutical reception on the Qur'anic verses, and not only hermeneutical reception in textual material. While with social media, this paper limits to Facebook. This study will take posts, captions, or comments social media users in their accounts in which the Qur'an, and/or its translations, and/or commentaries are available. The paper addresses two points: the character of the Qur'an commentary presented in Facebook within the context of modern Qur'anic commentary and the effects in public. ${ }^{16}$ The paper argues that social media has changed the configuration of contemporary exegesis in two ways: presentation and authorship. In this digital world, Qur anic commentary tends to be modest and simple, and at the same time, the equality and democratization of participation in hermeneutical activity and challenge of authority is available.

15 Stefani Ribka, "As illiteracy rate lowers, RI struggles with reading habits", The Jakarta Post (24 Mar 2016), http://www.thejakartapost.com/news/2016/03/24/ as-illiteracy-rate-lowers-ri-struggles-with-reading-habits.html, accessed 27 Sep 2017.

16 The current article is a follow up to my other article entitled "Tafsir Sosial Media di Indonesia". It discusses the hermeneutical directions of the Qur'an commentary in the social media, namely textual, contextual, and tafsir al-ilm. The current article however talks about the character of digital hermeneutics in the different direction, namely the context of the modern Qur'an commentary. It also talks about the effect of the digital hermeneutics in the different way. While there are some arguments in the current article which have by passing been mentioned in the previous one, the current contains a deeper elaboration. Fadhli Lukman, "Tafsir Sosial Media Di Indonesia", Nun: Jurnal Studi Alquran dan Tafsir di Nusantara, vol. 2, no. 2 (2016), pp. 117-40. 


\section{B. The Popularising Commentaries as a Modern Commentary}

It is worth noting that not many Qur'anic commentary authors use Facebook to publish their works. Quraish Shihab, for example, as one of the leading and most popular Qur'anic commentator in Indonesia, has a Facebook or a Fan Page account, but these accounts do not present the Qur'an commentary. Quraish Shihab has given Qur`anic commentary in social media in a question-answer style through his daughters' accounts. As he takes video platform, his commentary will not be discussed this paper. For this reason, my selection will introduce the other popular names; each of them represents a distinctive attitude in taking the Qur'an, translation, and commentary into their Facebook accounts. They are Salman Harun, Buya Gusrizal Gazahar, and Irena Handono. I also present various examples from numbers of Facebook users with regard to the Qur'an related materials in social media.

Salman Harun is one of the active Facebook users who writes posts in his Facebook with Qur'anic contents. He is a professor of Exegesis Studies in Syarif Hidayatullah State Islamic University Jakarta. He regularly writes his commentary of the Qur'an. He only explains the meaning of one verse per post and two or more verses when possible. Facebook is only his alternative platform to deliver his Qur'an commentary besides radio broadcast and books. Back in August $1^{\text {st }}, 2009$, in his first post, he wrote "Saya senang menafsir Al-Qur'an. Lihat Salman Harun Institute Geogle Blog Spot. Com (sic.). Dan saya suka ceramah. Dengar RRI Jakarta Pro 1 frekuensi 91.2 setiap pukul 5.15 pagi. Wasalam." In the beginning, he did in his web page, namely Salman Harun Institute. ${ }^{17}$ In this webpage, he has fifty-five articles. Until mid 2013, he used his Facebook only to show the excerpt of the original article he posted in the web. Facebook account was only a terminal to his original post, where he indicated his reader to refer directly to the webpage. His attention to webpage shifted completely to Facebook since 2013, that he has not posted articles on webpage any longer, but directly in his Facebook account. He only posted two articles in 2013 in the webpage.

He started to use Facebook since August 2009. Salman Harun was an active Facebook user only after May 2013. He was just a regular

17 Salman Harun, Personal Website, Salman Harun Institute, January 2009, http://salmanharun-institute.blogspot.com/ 
Facebook user back then; he wrote anything besides Qur'an related materials. He mostly wrote proverbs or reflections. Since June 2013, he appeared to intensify his writings with prophetic traditions and the Qur'an commentaries. His selection of verses seems to be random at some cases and/or as the responses to actual issues on the other instances. For example, he wrote his critics and evaluations on sermons delivered in Jum'ah prayer. In July 2013 he wrote many posts about moon-sighting (ru'yat al-hilä) and other Ramadhan-related verses. In this case, the compilation of his posts in this period is a separated-thematic commentary. In September 2013, with help of his student, he created Fan Page account. He also upgraded his webpage to salmanharun.com. The Fan Page contains the earlier version of his Facebook account; to share the excerpt of his newest post. As his previous webpage, the upgraded one is better in term design, however does not update its contents.

The second user in this paper is Buya Gusrizal Gazahar. He is the renowned ulama and the chief of Indonesian Ulama Council (Majelis Ulama Indonesia/MUI) of Sumatera Barat. The term 'Buya' is used to refer to ulama, similar to Buya Hamka (the author of Tafsir al-Azhar and the first chief of MUI) or Buya Syafi'i Ma'arif (the leading figure of Muhammadiyah). Gazahar is an active preacher in Sumatera Barat. He built a surau in which he is the Imam and the teacher. With his surau, he campaigns for Gerakan Ulama Baliak Basurau (the ulama back to surau movement). It is the movement to reproduce the reformation of Islamic education in West Sumatera before the Paderi movement (XIX century), when a certain ulama was based on one particular surau. He is an active Facebook user as he regularly writes things, answers the comments, also shares some links captioned with his own thoughts. As he is an ulama, it is well understood that he often quotes, translates, and interprets the Qur'an in his daily activity and in his Facebook account. He shares the audios of his sermons. He also writes his religious thoughts and advises. He quotes the Qur'an, its translation, and gives some explanation for his followers. The topics mostly deal with his concerns about people's socio-religious life. He is also responsive to many actual issues.

The third figure selected here is Irena Handono. She was formerly a pastor who converted to Islam and now is a muballighah (woman preacher) and a guide for the newly convert people. Her conversion was a big 
controversy and the story was spread widely in internet. She founded a pesantren and preaches regularly in many mosques. She is also an active Facebook user. She posts on daily basis. As a preacher, she gives religious advice and qoutes the Qur'an and prophetic traditions. As a convert, her concerns much related to inter-religious issues, particularly between Islam and Christianity with an apologetic approach. She is also reactive to many issues, such as terrorism, woman and Islam, political Islam, etc.

Her conversion story reveals that she learned Islam through Qur'an translation. She admits that she did not even know how to read the Qur'an. Based on her experience, on her post in July $9^{\text {th }}, 2016$, she wrote how Muslim should learn the Qur'an. As the first command revealed to Muhammad is to read (iqra), the way to regain life under the light of Islam is by reading the Qur'an. She suggests Muslim to read the Qur'an in three steps. The first step is to recite the Qur'an. This necessarily refers to the act of reciting the Qur'an as the expression of piety and devotion. The next step is to read its translation. It is interesting that she limits Qur'an translation (artinya), not explanation or commentary (tafsirnya). Her final step is to practice the Qur'an in daily experiences. She expresses her concern about how people only recite the Qur'an without understanding translation and practice in life.

Our three figures have no other way except to follow the way Facebook works; write posts. They express idea about a certain Qur anic verse in the provided post feature of Facebook. Their audiences are the connected facebook accounts. Their posts have special interactions from likes, shares, comments, and reports. Like is the representation of appreciation. Comments and shares could be either appreciation or criticism, depending on its content. Report is a non-verbal criticism, requesting Facebook to ban a certain post, or the whole account. Each post appears in the user's wall and every connected Facebook accounts. Comment enable them to interact with their audiences. Many are thankful for the valuable advices or religious reminders, the others express their approval, or show good manner with asking permission to share the posts. Some others ask question, and occasionally our three figures reply. The answer appears in the reply following the comments, or in a new specific post. If one particular post manages to attract great attentions, the post will remain on top of newsline. If another account, a second 
user, shares a specific post, it will appear as the second post and also naturally appears in the connected accounts to that second accounts. That is how it works for the next shares and so forth. Facebook spreads its content fast beyond geography. However, a particular post will lose attentions, and any new post from other account will come.

The Qur`anic commentaries used to be the exclusive affairs on an ivory tower. Al-Ṭabari collect dozens of riwwàyah, al-Rāzì and al-Qurțubī compile numbers of masā $i l$, and al-Zamakhsyari provide pages of linguistic analysis on one particular phrase or verse. ${ }^{18}$ Muhammad Abduh poses protest that commentaries have put the Qur`an away from Muslims, while the commentators were busy with a sophisticated discussion on the Qur an apart from the need of society, so that he calls to return to the Quran as for what it is intended, as hidayah to the mankind. ${ }^{19}$ Abduh's calls modernizing commentary, where an empirical and socio-political problem of the society should be put in the context. This new paradigm has brought a new face of commentaries; it becomes more friendly to broader readership. Johanna Pink identifies popularising commentaries as the published commentaries in mass-media, from which the exegesis gains journalistic form. The characteristics of this exegesis according to Pink is that they are intended to give a direct impression for a broader readership. "They are", Pink says, "closer to a sermon than to a detailed explanation of the meaning of particular ayah. ${ }^{20}$ In Indonesian context,

18 Description about what commentators do is found in writings about the history of tafsir tradition or tafsir as a literary genre. See Muhammad Husayn al-Dhahabī, Al-Tafsì Wa Al-Mufassirūn (Beirut: Maktabah Mus`ab ibn `Umair al-Islāmiyyah, 2004); Norman Colder, "Tafsīr from Tabarī to Ibn Kathīr: Problem in the Description of a Genre, Illustrated with Reference to the Story of Abraham", in Approaches to the Qur'ān, ed. by G.R. Hawting and Abdul-Kader A. Shareef (London: Routledge, 1993), pp. 101-40; Jane Dammen McAuliffe, "The Task and Traditions of Interpretation", in The Cambridge Companion to the Qur'an, ed. by Jane Dammen McAuliffe (Cambridge: Cambridge Universitry Press, 2006), pp. 181-120.

19 Muhammad Rashīd Riḍā, Tafsìr al-Manār (Cairo: Dār al-Manār, 1947), p. 19.

20 Johanna Pink, "Tradition, Authority and Innovation in Contemporary Sunn̄̄ Tafsìr: Towards a Typology of Qur'an Commentaries from the Arab World, Indonesia and Turkey", Journal of Qur'anic Studies, vol. 12, nos. 1-2 (2010), pp. 56-82.i.e. tafsīr musalsal — written by Sunnī authors from Egypt, Syria, Indonesia and Turkey between 1967 and 2004. For the purpose of analysis, it proposes a basic typology based on the author(s 
they are Qur'anic explanation in magazines in madrasah milieu in West Sumatera, al-Azhar of Hamka when it was in its formative period as a periodical article in an Islamic newspaper; in fact, Pink classifies Hamka's commentary as popularizing commentary even after its formation as Tafsir al-Azhar. In this new face of commentary, the main intention is not to discuss various voices in understanding one particular Qur anic phrase of verse, but rather to direct religious education for the reader. That is why Pink also characterizes it as an edification commentary, that is when the author provides his/her reflection on the verse he / she does not elaborate the scholarly analysis on the meaning of the verse. ${ }^{21}$

In this regards, the social media bridges the Qur'an translation/ commentary to Indonesian Muslims in the midst of minimums literacy awareness of Indonesians. The composition of digital Qur'anic commentary is simple and straightforward-in many instances it presents a mere translation - which becomes the characters of digital hermeneutics matching the need, interest, and the literacy culture of social media users. Digital hermeneutics is, therefore, a repercussion and a step forward to popularize and edification commentary. Pink's description matches hermeneutical activity of Gusrizal Gazahar and Irena Handono, and also matches that of Salman Harun. The three chose the popular medium to deliver their explanation of the Qur'an. They provide commentaries in a modest form with the simples language. Without employing sophisticated analysis of particular words or verses to make public understand the message, they give religious advises in their exegesis threads. They rarely indicate their references Buya Gusrizal Gazahar and Salman Harun some times indicate their references. In one of their posts, for examples, Buya Gusrizal Gazahar refers to al-Qurțubi while Salman Harun to Ibn Kathīr. What makes Salman Harun digital commentary irrelevant to Pink's description on popularizing commentary is his scholarly-inclined method.

Inquiries of the distinctive character of contemporary exegesis take two elements of novelty: contents and methods. ${ }^{22}$ Abdullah Saeed

21 Ibid., p. 61-62; 72.

22 Rotraud Wielandt, “Exegesis of the Qur'ān: Early Modern and Contemporary", Encyclopaedia of the Qur'an, ed. by Jane Dammen McAuliffe (Leiden: Brill, 2002), p. 124. 
traces it back to the criticism and the awareness to re-asses the tradition of Shah Wali Allah of India (d. 1762), Sayyid Ahmad Khan (d. 1898), and Muhammad Abduh (d. 1905), as they bridge the gap between reality and the Qur'an commentary. Abduh on the otherhand, dismisses the emphasis on philological and rhetorical features of the Qur'an. The answer comes not only in the practical commentary such as Abduh and Rida's al-Manār, but also in theoretical discussions about the new feasible methods of interpretation of the Qur'an. With the awareness of the historical context, the aim of the modern exegesis is to answer the political and social needs through the holistic meaning of the Qur'an. Amin alKhuli (d. 1966) develops a thematic approach emphasizing the relation between the text and historical context and the relation of one part of the Qur'an. Some prominent names such as 'Aisyah Abd al-Rahman bint al-Syati' (d. 1998), Abd al-Hayy al-Farmawi, Muhammad al-Ghazali (d. 1996), Sayyid Qutb (d. 1966), and Muhammad Husayn al-Tabataba'i adopt or are influenced by Amin al-Khuli's method. Fazlur Rahman (d. 1988), on the otherhand, emphasizes the importance of relation between the text and historical context and the contemporary context. ${ }^{23}$ It is fair to say that this approach is the antitheses of musalsal tafsir or tafsir tablili. The author in musalsal tafsir explains the meaning of the text. The author opens the muṣaf, sees the text, analyses and explains the meaning of the text. There is little awareness of socio-historical context. Asbāb al-nuг̄ul a minor role. The author follows the canonical order of the text. A different way applies to modern thematic approach. As the aim of this approach is to seek the answer for political and social questions of text, the author reads the text after seeing reality.

Digital hermeneutics works under the influence of modern exegesis, but it reduces an important aspect of it. Irena Handono and Gusrizal Gazahar of the text or write commentary on their Facebook account to provide religious answer to life problems. They responded to the issues of non-Muslim leaders for majority Muslims community, LGBT, interreligious or inter-madhhab problems, or moral crisis. They are aware that the Qur'an is relevant to these issues either directly or

23 Abdullah Saeed, "Introduction: the Qur'an: Interpretation and the Indonesian Context", in Approaches to the Qur'an in Contemporary Indonesia, ed. by Abdullah Saeed (Oxford: Oxford University Press, 2005), pp. 3-4. 
indirectly, and therefore it can provide problem-solving. They pick those verse, copy, and give a straight and simple explanation and explains how it works to solve the problem. Even though they have the same awareness with Syah Wali Allah (d. 1762), Sayyid Ahmad Khan (d. 1898), and Muhammad Abduh (d. 1905) that an exegesis has to answer the social problems, they lack intention to seek and to provide a holistic meaning of the Qur'an. This is because they do not employ the thematic method of interpretation which is one important element in modern exegesis.

Salman Harun deserves a more detail look. He has passed through dynamic methods of presenting his Qur'an commentary in his Facebook account. His initial digital Qur'anic commentary resembled that of Gusrizal Gazahar: providing religious advice to life problem. Afterwards, during Ramadhan in 2013, he conducted a disjointed thematic commentary. Gazahar also discussed Ramadhan related verses in a numbers of interrelated posts. The model of Gusrizal Gazahar and Irena Handono is typical description of digital hermeneutics, this two phases of Salman Harun commentary are digital hermeneutics. However, in 2014, he spent 4 months to provide interpretation for a complete surab Yūsuf and has shifted to a reverse musalsal/ tablili commentary, starting from the last surah moving forward. Therefore, his commentaries do not match the modern commentary, with the aim to bridge the reality and commentary and gain a holistic meaning of the Qur'an on a particular topic. What he does is a representation of the classical tafsir in a popular and modern medium. Accordingly, with this latest development, the term digital is relevant to the platform where he does not contextualise his commentary to the need and interest of social media users.

\section{The Upsurge Semantic Function of the Qur'an}

Our three figures present two different ways of employing the Qur an in the social media. Irena Handono provides the translation of the Qur'an without Arabic text. Following her Facebook posts, it is obvious that this is her typical way to interact with her followers in the social media. She does not indicate which translation she quotes. In many cases, she likely uses Al-Quran dan Terjemabnya of the Ministry of Religion. In the other instances, however, her translations are not identical to $\mathrm{Al}$ Quran dan Terjemahnya. In one occasion, she seems to quote translation of 
Qur'an, 7:178 from Al-Quran dan Terjemabnya of the Ministry of Religions, however, the original translation does not have the brackets "(dalam semua kebaikan dunia dan akbirat)". I do not know where she refers to for the text in brackets, I have little information about her mastery in Arabic.

In many other instances, Irena Handono provides more than a translation of the Qur an. She also provides her own interpretation. They are commonly brief commentaries. She does not provide an analysis of particular words. Nor does she quote authoritative commentators (mufassirün) in Islamic scholarship traditions. It seems that she is comfortable to gives her own opinion about the verse. In the other post, she advises people to come to the guidance of Allah and leave behind the belief of trinity.

Unlike Irena Handono, our two figures write the Arabic text of the Qur'an along its translation. Buya Gusrizal Gazahar, with his intellectual authority and mastery in Arabic, translates the verses by himself. He does not indicate the similarities between the translation in his Facebook account and Al-Quran dan Terjemahnya of Ministry of Religions. He consistently writes the Arabic verse followed by the translation. On the other hand, Salman Harun evolves in the way he quotes the Qur'an. In the early days, he wrote his message and indicated the number of surahs and verses without text and translation. He then wrote its translation. $\mathrm{He}$ seems personally translate the Qur'an verses which does not resemble any translation available in Indonesia. In one particular post, he asked his audiences about the way to install Arabic typescript in computer.

Irena Handono's method gives an impression that providing a translation of the Qur'an, without Arabic text or without explanation becomes a source of religious guidance. There are more people now employ the same method, either they write the translation or share a capture of a Quran translation on a particular verse with a short reflection. This means that more people interact with the translation of the Qur an in their social media accounts, a phenomenon which shows a growing trend in semantic function of the Qur an. This is a different trend from the last century, that the translation of the Qur an was forbidden, Kartini says:

“... And, it truth, I am a Moslem only because my ancestors were. How can I love the doctrine which I do not know-may never know? The 
Koran is too holy to be translated into any language whatever. Here no one speaks Arabic. It is customary to read from the Qur'an; but what is read no one understand! To me it is a silly to thing to be obliged to read something without being able to understand it... If I wish to know and understand our religion, I should go to Arabia to learn the language. Nevertheless, one can be good without being pious." ${ }^{24}$

Kartini's protest reflects the accepted theological view of the translation of the Qur'an. Kartini was right that theologians believe that any translation of the Qur'an is not the Qur'an. Rashid Rị̣a, Mușțafa alMarāghi, Mannā` Khalīl al-Qaț̣ān, al-Zarqāni, are of the opinion. ${ }^{25}$ In the Indonesian context, the argument over the translation of Tjokroaminoto were brought internationally by Basyuni Imran of Sambas, as he wrote his teacher, Rashid Rida, who challenged the translation of the Qur'an in Turkey and in India. ${ }^{26}$ Sayyid Uthmān, a Dutch-allied Ulama, challenged a Javanese Qur'an translation. In 1909, he challenged the effort to translate the Qur'an in a pamphlet called Hukm al-Rabmann bi al-Naby 'an Tarjamah al-Qur an. He condemned the translation of the Qur an deemed distortion (tabri îj), change (tabdī), and blasphemy (ihänah). Ichwan suggests this prohibition of Sayyid Uthmān has colonial agenda to limit Indonesian Muslims' effort to understand the Qur'an. ${ }^{27}$

This theology is an explanation of the marginalized role of hermeneutical reception of the Qur'an in Indonesian Muslims, and of performative function of the Qur`an until mid-twentieth century. The lack of understanding Arabic hinder them from knowing meaning of the

${ }^{24}$ R.A. Kartini, Letters of a Javanese Princess, ed. by Hildred Geertz, trans. by Agnes Louise Symmers (New York: W. W. Norton, 1964), p. 44.

25 Fadhli Lukman, "Studi Kritis atas Teori Tarjamah Alquran dalam Ulum Alquran”, Al-A'raf: Jurnal Pemikiran Islam dan Filsafat, vol. 13, no. 2 (2016), pp. 167-90.

26 Ahmad Najib Burhani, "Sectarian Translation of the Qur'an in Indonesia: The Case of the Ahmadiyya", Al-Jami'ah: Journal of Islamic Studies, vol. 53, no. 2 (2015), pp. 251-82; Moch Nur Ichwan, "Differing Responses to an Ahmadi Translation and Exegesis. The Holy Qur'ân in Egypt and Indonesia”, Archipel, vol. 62, no. 1 (2001), p. 148.

27 Moch Nur Ichwan, "Negara, Kitab Suci, dan Politik: Terjemah Resmi alQur'an di Indonesia”, in Sadur: Sejarah Terjemahan di Indonesia dan Malaysia, ed. by Henri Chambert-Loir (Jakarta: Kepustakaan Populer Gramedia \& Ecole Française d'ExtrêmeOrient, 2009), p. 418; Nur Ichwan, "Differing Responses to an Ahmadi Translation and Exegesis. The Holy Qur'ân in Egypt and Indonesia", p. 145. 
Qur`an. Their access to semantic function of the Qur`an only possible with the intermediary of local religious leader. Ahmad Rafiq suggests that, Indonesian people, particularly Banjarese, 'emphasizes the oral tradition of the Qur 'an, which is corroborated by the written one.' Rafiq does not exclude the hermeneutical reception. The prime example is interesting practice during childbirth, where a local religious leader provides the mother with water with prayer. The formula of the prayer is al-Fātihah (1): 1-7 and al-bākum't-takeathur (al-Takāthur, 102: 1) combined with 'mudah-mudahan bayinya keluar mendusur'. Mendusur is Banjarese word for 'fast and easy'. In this case, the local leader associate the ending sound of takäthur with mendusur, although the verse has to do with childbirth. ${ }^{28}$

With the Qur'an translation and the social media, however, the history of the Qur'an in Indonesia has come to the new face. Now, hermeneutical reception of the Qur'an has been prevalent. It even reaches the limit that people equalize the translation to the Arabic Qur'an. It is well represented in a controversy of fraudulent Qur'an, where a translation of Qur'an, 5:51 become a point of controversy. At the end of October 2016, people reacted to the differences in the translation alwiya $\bar{a}$ in Qur'an, 5:51. A number of the translations of the Qur'an in Indonesia renders awliy $\bar{a}^{\prime}$ as pemimpin (leaders). After one month of controversy discussing the correct translation for awliyä, caused by a blasphemous speech in Kepulauan Seribu by Basuki Tjahaja Purnaka a.k.a Ahok, people know that awliya a' can mean teman setia (a loyal friend). Internet reacted, led by a member of Regional Representative Council, Fahira Idris (@ fahiraidris), and an activist, such as Mustafa Nahra (@TofaLemon).Nahra claimed that he had received an information revealing that a number of fraudulent Qur'ans were distributed. Even though he was aware that the difference was in translation, he explicitly referred to "Al-Qur'an palsu" (the fraudulent Qur'an). He then urged people to inspect book stores and sweep any text. Fahira Idris was as reactive as Nahra, as she said to have called a particular publishing house to be responsible. She expressed it as 'mengedit Al-Quran' (to edit the Qur'an), in her tweets, instead of 'mengedit terjemahan' (to edit translation). Both Nahra and Idris were the active twitter users and invite people to respond. Therefore, many people

${ }^{28}$ Rafiq, "The Reception of the Qur'an in Indonesia: a case study of the place of the Qur'an in a non Arabic speaking community", p. 82. 
captured their mushaf on Qur'an, 5:51, posted it with some interesting captions. ${ }^{29}$ While this phenomenon has a specific political context which triggers exaggerated response, the way they define fraudulent based on its interpretive dimension, namely the difference in translation, shows a perception that a particular interpretation of the Qur`an can dissolve the sacred status of the scripture. They assume the translation equal to the Arabic Qur`an.

\section{A Shift in Authorship and the Authority Contested}

It is clear that modernization in Islamic thought has brought tafsir into popular face through journalistic commentary and social media. However, the influence of modernity only apparent in its product from a scholarly-sophisticated analysis to a popular reader-friendly one. Social media has straightforward language. But it has an unprecedented dynamic where there has been also shift in authorship.

Qur'an commentaries have been dominated by men in Islamic intellectual history. Amina Wadud two decades ago, ${ }^{30}$ followed by Aisha Geissinger question the exegetical materials attributed to man. Geissinger suggests that the interpretive authority was illustrated as 'emblematically masculine,' and women were marginalized as 'materials not exegetically definitive. ${ }^{31}$ This fact applies not only for the classical commentaries, but

29 Purnawan Setyo Adi, "Dituding Terbitkan Al Quran Palsu, Penerbit Yogya Lapor Ke Polisi”, GatraNews (2016), https:/ /www.gatra.com/nasional/pemerintahanpusat/223158-dituding-terbitkan-al-quran-palsu-penerbit-yogya-lapor-ke-polisi, accessed 23 Nov 2017; Kabul Astuti, "Soal Perubahan Tafsir Al Maidah 51, Fahira akan Tanyakan Kemenag", Republika Online (23 Oct 2016), https://www.republika. co.id/berita/nasional/umum/16/10/23/ofgnj0361-soal-perubahan-tafsir-al-maidah51-fahira-akan-tanyakan-kemenag, accessed 23 Nov 2017; Ahmad Muhajir, "Fahira Idris Benarkan Ada Perubahan Terjemah al-Qur'an”, Gontornews (24 Oct 2016), https:/ / gontornews.com/2016/10/24/ fahira-idris-benarkan-ada-perubahan-terjemah-alquran/, accessed 23 Nov 2017; Soal Terjemahan Awliyâ Sebagai "Teman Setia", Ini Penjelasan Kemenag (23 Oct 2016), https://www2.kemenag.go.id/berita/417806/soal-terjemahanawliy-sebagai-teman-setia-ini-penjelasan-kemenag, accessed 23 Nov 2017.

30 Amina Wadud, Qur'an and Woman: Rereading the Sacred Text from a Woman's Perspective (Oxford, New York: Oxford University Press, 1999), p. 2.New York: Oxford University Press, 1999

31 Aisha Geissinger, Gender and Muslim Construction of Exegetical Authority: A Rereading of the Classical Genre of Qur'än Commentary (Leiden: Brill, 2015), pp. 273-80. 
also to the contemporaries; it is not a coincident that all commentators in Arab world, Turkey, and Indonesia are men. ${ }^{32}$ In Indonesia alone, works reviewing literatures related to the Qur'an only mention men authors. Howard Federspiel studies sixty books from the beginning of twentieth century up to 1987; all are written by men. ${ }^{33}$ While Federspiel's work does not deal specifically with commentaries books, Islah Gusmian does with this particularity for literatures between 1960-1990, while M. Nurdin Zuhdi does the same study between 1990-2010. ${ }^{34}$

Irena Handono is a female Facebook users who presents the Qur'an and translation. Our examples from Muslims consisted of both men and women. The existence of, and appreciation for, Irena Handono marks the equality of participation in Qur'an commentary for woman. Her role is interesting with regard to the conventional construction of interpretive authority of the Qur'an. The history of masculine interpretive authority does not seem to burden the existence of Irena Handono in the digital hermeneutics. Compared to the above figures, she gets the most appreciation with likes, comments, and shares. She delivers the straightest message among and often deals with sensitive interreligious polemics in the context of Indonesia.

As in the foregoing discussion, the modest and straightforward language of digital hermeneutics has brought an increasing significance of semantic function of the Qur'an among Indonesian Muslims. The technical appearance of Qur'an commentary which allows the presence of a mere translation of the verses and a simple reflection or religious advices has created an impression that the Qur'an commentary are simple. Accordingly, this is the kind of exegesis people recognize. Not only do social media users read those commentaries, the presence of their own reflection and opinion to specific verses are also prevalent. Social media brings tafsir to the democratization of participation; not only is it produced by a renowned ulama, it also come from social media users.

32 Johanna Pink, “Tradition and Ideology in Contemporary Sunnite Qur'ānic Exegesis: Qur'ānic Commentaries from the Arab World, Turkey and Indonesia and their Interpretation of Q 5:51", Die Welt des Islams, vol. 50, no. 1 (2010), pp. 3-59.

33 Federspiel, Popular Indonesian Literature of the Qur'an; Didin Syafruddin, "Karakter Literatur Indonesia tentang al-Qur'ān", Studia Islamika, vol. 2, no. 2 (1995), pp. 165-95.

34 Gusmian, Khazanah Tafsir Indonesia; Zuhdi, Pasaraya Tafsir Indonesia. 
In the early twentieth century period, Federspiel proves his hypothesis that Indonesian Qur'anic literatures were well-known in Southeast Asia because the authors are well educated people in Islamic disciplines. In today digital hermeneutics period, anybody can produce their Qur an commentary regardless their intellectual capacity. The different character between written literatures and social media determines point in this shift. Unlike posting posts in social media, writing books needs long procedures. It passes some steps from preparing sources and draft, writing, editing, and publishing the text. While writing a book is intended to academic reputation, posting a status in social media has no such burden.

The subtle way to do it is by engaging in facebook features of likes, comments, and shares. These features enable the social media users to shows their preference to a certain digital hermeneutics content. The most noticeable contents mostly come from public figures. From our three figures, Irena Handono's account typically gets more than one thousand likes. Buya Gusrizal Gazahar's account gets not as many likes as Irena Handono's, but he has the interactions with his audiences. Unlike Irena Handono and Buya Gusrizal Gazahar, Salman Harun does not have interaction as much as the previous figures. His likes, shares, and comments are less than both accounts. Clearly, his classic-scholarly-typed commentary does not attract much attention, and most likely is relevant to the need and the interest of the social media users. Interestingly, a more authoritative exepete was rejected and then disbanded by Facebook. One example of it is Sahiron Syamsuddin (his account was re-activated after one year). His interpretation of Qur'an, 5:51 in his personal facebook account ${ }^{35}$ realated to 2016 Jakarta Gubernatorial election attracts great negative attention, from which many has reported his account to Facebook, requesting to ban.

Not only employing features of likes, comments, shares, and report, people also engage in actual hermeneutical activity, that is when they quote a particular verse with or without its translation or provide their

35 The post is republished in the official website of State Islamic University Sunan Kalijaga Yogyakarta. Sahiron Syamsuddin, "Penafsiran Kontekstualis Atas Q.S. al-Ma’idah: 51” (14 Jun 2017), http:/ / uin-suka.ac.id/id/kolom/detail/20/penafsirankontekstualis-atas-qs-al-maidah-51, accessed 23 Dec 2011. 
own understanding and reflection on a certain verse of the Qur`an. Social media provides freedom to write personal opinion. In some instances, they can just post a picture of a Qur'anic verse and translation along with their personal reflection on it without any indication about the reason behind choosing the given verse. In many other instances, however, there are many users explicitly write their motive of quoting a Qur'anic verse in their Facebook account, that they do it with particular purposes, to response to the actual discourses everybody is talking about. They believe that, quoting the Qur'an and its translation can give guide to people on how to deal with the social and political problem.

People's confidence to write down their own reflection and understanding about the Qur'an in their social media might also have strong connection to the high numbers of the availability of Qur'an translation in Indonesia. The Qur'an translation has brought the Quranic interpretation from a limited educational setting in mosque or madrasah to a personal and private sphere; and social media becomes means by which people spread their ide on its hermeneutics. The Qur an translations, either in published edition or digital version, play role as source of knowledge in digital hermeneutics. This has made possible all people, regardless their lacking or mastery in Arabic and Islamic intellectual history, to engage with the meaning of the Qur`an. Digital hermeneutics is can be considered as an indicator that the project of Qur'anic translation in Indonesia is successful. ${ }^{36}$ The intensity of Muslims interactions with the Qur'an in their social media accounts reflects their enthusiasm as non-Arabic speakers to learn the Qur'an from its

36 Unlike the polemical motive in the translations of the Qur'an in Western world, the effort to translate the Qur'an in modern Indonesia was from the first place intended to bridge the Qur'an and Indonesian non-Arabic speaker Muslims. This motive is explicitly mentioned in many places such as by Tjokroaminoto in his unfinished translation, Soekarno, Idham Khalid, and Saifuddin Zuhri in the official translation of the Ministry of Religion, and Mahmud Yunus in the cover of the early edition of his translation of the Qur'an. See Jajasan Penjelenggara Penterdjemah Pentafsir al Quräan, Al Qur'an dan Terdjemahnja (Djakarta: JAMUNU, 1965); Mahmud Yunus, Tafsir Quran Karim Bahasa Indonesia (Djakarta: Pustaka Mahmudiah, 1957); Ziad Elmarsafy, The Enlightenment Qur'an: The Politics of Translation and the Construction of Islam (Oxford: Oneworld Publications, 2009); Ziad Elmarsafy, “Translations of the Qur'an into Western Languages”, Religion Compass, vol. 3, no. 3 (2009), pp. 430-9; Burhani, "Sectarian Translation of the Qur'an in Indonesia". 
translation. They even their understanding of the Qur'an on translation as seen in the way they judge and discuss the Qur'an in social media.

One particular account represents an interesting phenomenon; the Qur'an translation is used to create a personal brand. It is the account of a person who is in the middle of preaching TV competition, namely Akademi Sabur Indonesia. He was one step away from being nominated for the national level held in Ramadhan in 2016. The way the competition works is similar to 'The Voice' or 'Indonesian Idol'; the winner is selected by people, by their votes through sms votes. It is a common feature in this kind of competition, that participants attempt to persuade as many supporters as possible through social media campaigns. As this is a competition of so-called mastery in preaching in which people's perception of participants' knowledge on Islam and on the Qur'an is the most important matter, they will represent themselves as knowledgeable through their social media content filled with Islamic or Qur'anic-related materials.

A shift is not the only in authority in this context. A scholarly opinion from an established scholar or ulamä can be challenged by lay people who refer his argument merely to a Qur`an translation. A social media debate involving Nadirsyah Hosen, a professor on Islamic law, might be the best example. In his facebook account, he posts his argument questioning a campaign forbidding people from supporting non-Muslim leader in Muslim majority country. ${ }^{37}$ On the possibility of Basuki Tjahya Purnama or Ahok to continue his governorship in Jakarta, based on Qur'an, 5: 51 and Qur'an, 4: 144. He begins his post with a translation and does to translate the word 'awliy a', not. He quotes Ibn Kathīr who translate the word as the 'allies' (Hosen translates it as sekutu) instead of 'leader' (pemimpin). As it is the heated issue, his post generated responses; pros and contras. In one of his answer to his fellow's comment, he even adds 10 more commentaries; Al-Baị̣āwi, Jalālayn, al-Khāzin, Muqātil ibn Sulaymān, to name some. What interesting is that his scholarly approached is responded by people with their reliance on a translation.

37 His post is republished in official website of Nahdlatul Ulama. Nadirsyah Hosen, "Meluruskan Sejumlah Tafsir Surat Al-Maidah 51", NU Online (10 Dec 2016), http://www.nu.or.id/post/read/71937/meluruskan-sejumlah-tafsir-surat-al-maidah-51, accessed 12 Oct 2016. 
Given Nadirsyah Hosen promotes, whether in this particular post and elsewhere, that the debate within certain verses of the Qur'an are large and rich, beyond a mere translation can represent, people just dismiss Hosen's argument and base their knowledge on a translation. Here we see a debate between a person with his sophisticated academics resources and people with a translation. Those who use a translation seems confident to understand it literally.

\section{E. Concluding Remarks}

The inquiry of the digital hermeneutics in this papers reveals some interesting points. Social media has changed the configuration of contemporary exegesis in two ways. Modernization of Islamic thought had changed the presentation of Qur`anic commentary from a scholarly approach to a popular format, while social media has brought into a step further a simpler and straightforward commentary from which an upsurging of the semantic function of the Qur'an is seen. Digital hermeneutics is the Qur'an commentary presented in digital platform in a modest language taking the readers to a direct religious advice without being bothered by a sophisticated analysis about the meaning of a certain word or verse or by the fact that there in fact are various voices on the meaning of a certain word or verse. Digital tafsir has one part of modern commentary spirit, namely to bridge the Qur'an to the social problem, but neglect the other integral part of it, namely the aim to achieve the holistic meaning of the Qur'an. In this regards, Gusrizal Gazahar and Irena Handono related materials in their Facebook accounts, typical examples of a digital hermeneutics. Salman Harun, however, has a limited parallel to the description of both modern commentary and digital hermeneutics. He applies a classic-scholarly-type commentary.

The other striking phenomenon brought into surface by digital hermeneutics is the equality of interpretive authority between man and women. The history of Qur'an commentary has consistently illustrated interpretive authority as masculine. There is democratisation in the participation in Qur'an commentary. The availability of Qur'an translation is social media has brought tafsir from an exclusive affairs into a personal and private sphere, in which the Qur'an commentary is not only the affairs of the elites but also of all social media users. As the Qur`an 


\section{Fadhli Lukman}

commentary is now becoming closer to people, there is democratization of participation in hermeneutical activity and a challenge to authority. 
Digital Hermeneutics and a New Face of the Qur`an Commentary

\section{BIBLIOGRAPHY}

Adi, Purnawan Setyo, "Dituding Terbitkan Al Quran Palsu, Penerbit Yogya Lapor Ke Polisi”, GatraNews, 2016, https://www.gatra.com/ nasional/pemerintahan-pusat/223158-dituding-terbitkan-al-quranpalsu-penerbit-yogya-lapor-ke-polisi, accessed 23 Nov 2017.

Astuti, Kabul, "Soal Perubahan Tafsir Al Maidah 51, Fahira akan Tanyakan Kemenag", Republika Online, 23 Oct 2016, https://www. republika.co.id/berita/nasional/umum/16/10/23/ofgnj0361 soal-perubahan-tafsir-al-maidah-51-fahira-akan-tanyakan-kemenag, accessed 23 Nov 2017.

Burhani, Ahmad Najib, "Sectarian Translation of the Qur'an in Indonesia: The Case of the Ahmadiyya", Al-Jami'ah: Journal of Islamic Studies, vol. 53, no. 2, 2015, pp. 251-82 [http://dx.doi.org/10.14421/ ajis.2015.532.251-282].

Colder, Norman, "Tafsīr from Tabarī to Ibn Kathìr: Problem in the Description of a Genre, Illustrated with Reference to the Story of Abraham", in Approaches to the Qur'an, ed. by G.R. Hawting and Abdul-Kader A. Shareef, London: Routledge, 1993.

al-Dhahabī, Muhammad Husayn, Al-Tafsìr Wa Al-Mufassirūn, Beirut: Maktabah Mus`ab ibn `Umair al-Islāmiyyah, 2004.

Elmarsafy, Ziad, The Enlightenment Qur'an: The Politics of Translation and the Construction of Islam, Oxford: Oneworld Publications, 2009.

----, “Translations of the Qur'an into Western Languages", Religion Compass, vol. 3, no. 3, 2009, pp. 430-9 [http://dx.doi.org/10.1111/ j.1749-8171.2009.00140.x].

Federspiel, Howard M., Popular Indonesian Literature of the Qur'an, Ithaca (NY): Cornell modern Indonesia project, Southeast Asia program, Cornell University, 1994.

Gade, Anna M., Perfection Makes Practice: Learning, Emotion, and the Recited Qur'an in Indonesia, Honolulu: University of Hawai'i Press, 2004.

Geissinger, Aisha, Gender and Muslim Construction of Exegetical Authority: A Rereading of the Classical Genre of Qur'an Commentary, Leiden: Brill, 2015. 
Gorke, Andreas, "Redefining the Borders of Tafsìr: Oral Exegesis, Lay Exegesis and Regional Particularities", in Tafsir and Islamic Intellectual History: Exploring the Boundaries of a Genre, ed. by Andreas Görke and Johanna Pink, London: Oxford University Press, 2014.

Graham, William Albert, Beyond the Written Word: Oral Aspects of Scripture in the History of Religion, Cambridge: Cambridge University Press, 2001.

Gusmian, Islah, Khazanah Tafsir Indonesia: Dari Hermeneutika bingga Ideologi, Yogyakarta: LKiS, 2013.

Hosen, Nadirsyah, "Meluruskan Sejumlah Tafsir Surat Al-Maidah 51 | NU Online”, NU Online, 10 Dec 2016, http://www.nu.or.id/ post/read/71937/meluruskan-sejumlah-tafsir-surat-al-maidah-51, accessed 12 Oct 2016.

----, Tafsir al-Quran di Medsos, Yogyakarta: Bentang Pustaka, 2017.

Ichwan, Moch Nur, "Negara, Kitab Suci, dan Politik: Terjemah Resmi al-Qur'an di Indonesia", in Sadur: Sejarah Terjemahan di Indonesia dan Malaysia, ed. by Henri Chambert-Loir, Jakarta: Kepustakaan Populer Gramedia \& Ecole Française d'Extrême-Orient, 2009, pp. 417-33.

Jajasan Penjelenggara Penterdjemah Pentafsir al Quräan, Al Qurän dan Terdjemahnja, Djakarta: Jamunu, 1965.

Kartini, R.A., Letters of a Javanese Princess, ed. by Hildred Geertz, trans. by Agnes Louise Symmers, New York: W. W. Norton, 1964.

Kementrian Kominfo, "Kominfo: Pengguna Internet di Indonesia 63 Juta Orang," Kementrian Komunikasi dan Informatika, November 7, 2013, https://kominfo.go.id/index.php/content/detail/3415/Ko minfo+:+Pengguna+Internet+di+Indonesia+63+Juta+Orang/0/ berita_satker., accessed 22 June 2017.

Lukman, Fadhli, “Tafsir Sosial Media Di Indonesia”, Nun: Jurnal Studi Alquran dan Tafsir di Nusantara, vol. 2, no. 2, 2016, pp. 117-40.

----, "Studi Kritis atas Teori Tarjamah Alquran dalam Ulum Alquran", Al-A'raf: Jurnal Pemikiran Islam dan Filsafat, vol. 13, no. 2, 2016, pp. 167-90 [http://dx.doi.org/10.22515/ajpif.v13i2.262.].

McAuliffe, Jane Dammen, “The Task and Traditions of Interpretation”, in The Cambridge Companion to the Qur'an, ed. by Jane Dammen McAuliffe, Cambridge: Cambridge Universitry Press, 2006. 
Muhajir, Ahmad, "Fahira Idris Benarkan Ada Perubahan Terjemah al-Qur'an", Gontornews, 24 Oct 2016, https://gontornews. com/2016/10/24/fahira-idris-benarkan-ada-perubahan-terjemahal-quran/, accessed 23 Nov 2017.

Nur Ichwan, Moch, "Differing Responses to an Ahmadi Translation and Exegesis. The Holy Qur'ân in Egypt and Indonesia", Archipel, vol. 62, no. 1, 2001, pp. 143-61 [http://dx.doi.org/10.3406/ arch.2001.3668].

Pink, Johanna, "Tradition, Authority and Innovation in Contemporary Sunnī Tafsìr: Towards a Typology of Qur'an Commentaries from the Arab World, Indonesia and Turkey", Journal of Qur'anic Studies, vol. 12, nos. 1-2, 2010, pp. 56-82.

---- “'Tradition and Ideology in Contemporary Sunnite Qur’ānic Exegesis: Qur'ānic Commentaries from the Arab World, Turkey and Indonesia and their Interpretation of Q 5:51", Die Welt des Islams, vol. 50, no. 1, 2010, pp. 3-59 [http://dx.doi.org/10.1163/157006010X489801].

Rafiq, Ahmad, "The Reception of the Qur'an in Indonesia: a case study of the place of the Qur'an in a non Arabic speaking community", Ph.D. Dissertation, Philadelphia: Temple University, 2014.

Rasmussen, Anne, Women, the Recited Qur'an, and Islamic Music in Indonesia, Berkeley: University of California Press, 2010.

Ribka, Stefani, "As illiteracy rate lowers, RI struggles with reading habits", The Jakarta Post, 24 Mar 2016, http://www.thejakartapost. com/news/2016/03/24/as-illiteracy-rate-lowers-ri-struggles-withreading-habits.html, accessed 27 Sep 2017.

Rị̣ā, Muhammad Rashīd, Tafsìr al-Manār, Cairo: Dār al-Manār, 1947.

Saeed, Abdullah, "Introduction: the Qur'an: Interpretation and the Indonesian Context", in Approaches to the Qur'an in contemporary Indonesia, ed. by Abdullah Saeed, Oxford: Oxford University Press, 2005.

Slama, Martin, "Practising Islam through Social Media in Indonesia", Indonesia and the Malay World, vol. 46, no. 134, 2018, pp. 1-4 [http:// dx.doi.org/10.1080/13639811.2018.1416798].

"Soal Terjemahan Awliyâ Sebagai “Teman Setia”, Ini Penjelasan Kemenag," 
23 Oct 2016, https://www2.kemenag.go.id/berita/417806/soalterjemahan-awliy-sebagai-teman-setia-ini-penjelasan-kemenag, accessed 23 Nov 2017.

Syafruddin, Didin, "Karakter Literatur Indonesia tentang al-Qur'ān”, Studia Islamika, vol. 2, no. 2, 1995, pp. 165-95 [http://dx.doi. org/10.15408/sdi.v2i2.839].

Syamsuddin, Sahiron, Penafsiran Kontekstualis Atas Q.S. al-Ma'idab: 51, 14 Jun 2017, http://uin-suka.ac.id/id/kolom/detail/20/penafsirankontekstualis-atas-qs-al-maidah-51, accessed 23 Dec 2011.

Wadud, Amina, Qur'an and Woman: Rereading the Sacred Text from a Woman's Perspective, Oxford, New York: Oxford University Press, 1999.

Wielandt, Rotraud, "Exegesis of the Qur'ān: Early Modern and Contemporary", Encyclopaedia of the Qur'an, ed. by Jane Dammen McAuliffe, Leiden: Brill, 2002.

Wilson, M. Brett, Translating the Qur'an in an Age of Nationalism: Print Culture and Modern Islam in Turkey, Oxford, New York: Oxford University Press, 2014.

Yunus, Mahmud, Tafsir Quran Karim Bahasa Indonesia, Djakarta: Pustaka Mahmudiah, 1957.

Zayd, Nasr Hamid Abu, "Everyday Life, Qur' ān In", Encyclopaedia of the Qur àn, ed. by Jane Dammen McAuliffe, Leiden: Brill, 2002.

Zuhdi, M. Nurdin, Pasaraya Tafsir Indonesia: Dari Kontestasi Metodologi hingga Kontekstualisasi, Yogyakarta: Kaukaba, 2014. 